\title{
Иванникова Л.В.
}

Инновационный потенциал внеаудиторной деятельности в образовательной среде вуза

Филиал ГБОУ ВО «Ставропольский государственный педагогический институт» в г.Буденновске

doi: $10.18411 / s r-10-04-2019-27$

(Россия, Буденновск)

idsp: sciencerussia-10-04-2019-27

\section{Аннотация}

В статье рассматривается инновационный потенциал внеаудиторной деятельности в образовательной среде вуза, способствующий стимулированию инновационной активности студентов, которая в свою очередь определяет готовность будущих педагогов к инновационной научной деятельности. Определяются условия формирования инновационной активности студентов, составляющие инновационной деятельности, качества и умения студентов для воплощения инновационных идей. Раскрывается роль нововведений во внеаудиторной деятельности.

Ключевые слова: инновационный потенциал, внеаудиторная деятельность, образовательная среда, инновационная активность, нововведения, инновационная педагогическая деятельность. 


\section{Abstract}

The article discusses the innovative potential of extracurricular activities in the educational environment of the University, contributing to the stimulation of innovative activity of students, which in turn determines the readiness of future teachers to innovative research activities. Conditions of formation of innovative activity of students, components of innovative activity, quality and abilities of students for the embodiment of innovative ideas are defined. The role of innovations in extracurricular activities is revealed.

Key words: innovative potential, extracurricular activities, educational environment, innovative activity, innovations, innovative pedagogical activity.

В современном мире во всех сферах общества, в частности в образовании, происходят значительные изменения. Большое значение вопросам инноваций уделяют в педагогическом образовании, поскольку именно оно подготавливает специалистов для всех других областей. В данное время без разработки и применения новых технологий не может развиваться ни одно предприятие, учреждение, ни одна организация.

Главным носителем инновационного потенциала считается молодежь. Поэтому государство всячески старается стимулировать ее инновационную активности.

Инновационная активность - комплексная характеристика инновационной деятельности, которая включает в себя степень интенсивности осуществляемых действий и их своевременность, способность мобилизовать потенциал необходимого количества и качества $[4$, с. 40$]$.

Инновационная активность формируется в аудиторной и во внеаудиторной деятельности под руководством преподавателя или в результате совместной самостоятельной научно-инновационной деятельности студентов.

Результатом самостоятельной познавательной деятельности является приобретение студентом новых, углублённых и упорядоченных знаний. Роль самостоятельной учебной деятельности особенно возрастает, так как большое внимание уделяется формированию у студентов высших учебных заведений потребности в постоянном самообразовании. Важность организации разнообразной самостоятельной деятельности со студентами детерминирована необходимостью разрешения противоречия между трансляцией знаний и усвоением их во взаимосвязи практики и теории. Самостоятельная деятельность своеобразна тем, что студент имеет возможность самостоятельно определять собственную научную траекторию и выступает субъектом своей же научно - познавательной деятельности[3, с. 70 - 71].

Изменения, происходящие в политике образования, коснулись и внеаудиторной деятельности студентов. Современное общество, как никогда раньше, нуждается в воспитании всесторонне развитой личности. При этом большое внимание уделяют выявлению и развитию творческих способностей учащихся. В связи с этим во внеаудиторную деятельность активно проникают нововведения.

Под нововведениями подразумеваются целенаправленные изменения, которые вносят в образование новые элементы и вызывают его переход из одного состояния в другое.

Возникают нововведения, когда в сложившийся учебно-воспитательный процесс, включают достижения современной педагогики и психологии, при этом опираются на передовой педагогический опыт.

Перед современной педагогикой стоит важная задача отобрать, изучить и классифицировать нововведения. Эти знания необходимы для подготовки молодых специалистов. Педагоги должны четко понимать сущность инновационных процессов во внеаудиторной деятельности, уметь осуществлять их с учетом специфических закономерностей и принципов.

Наше правительство рассчитывает использовать потенциал молодежи в интересах инновационного развития страны.

Для выполнения этого замысла в высших учебных заведениях нужно осуществлять инновационно-ориентированную подготовку педагогических и научнопедагогических кадров [5, с. 226]. 
Инновационная деятельность студентов предполагает:

— желание обучаться в течение всей жизни;

- постоянное совершенствование, переобучение и самообучение;

— профессиональную мобильность, влечение к новому;

- наличие критического мышления;

- креативность и предприимчивость;

— умения работать самостоятельно;

— умения работать в команде;

- умения быть конкурентоспособным;

- знание иностранного языка.

Сегодня студенты должны уметь быстро приспосабливаться к меняющимся потребностям общества. Нашей стране очень не хватает кадров с высоким уровнем инновационной культуры и профессиональных компетенций. Поэтому к внеаудиторной деятельности молодых специалистов предъявляют современные требования, которые предполагают использование новых методов обучения и новых форм контроля знаний.

Многие молодые специалисты стремятся к исследовательской и инновационной деятельности не ради денег, а чтобы иметь возможность для профессиональной самореализации. В этом случае учебное заведение должно создать необходимые условия для профессионального роста студентов.

Перед будущими педагогами стоит серьезная задача - воспитать личность, способную жить в обществе знаний.

Прежде, чем развивать инновационный потенциал и формировать инновационную активность студентов, необходимо создать развивающую инновационную научнообразовательную среду вуза. Учащиеся высших заведений должны иметь возможность разрабатывать, распространять и внедрять инновации совместно с опытными преподавателями [2, с. 38].

Данная деятельность требует решения многих задач:

- мотивировать студентов к созданию новых идей;

- развивать творческие способности молодежи;

- привлекать учащихся к научно-исследовательской деятельности;

- обеспечить эффективное взаимодействие между студентами и преподавателями, имеющими разные степени учености;

- дать учащимся возможность реализовать свои инновационные идеи и проекты;

— осуществлять поиск талантливых людей и помогать им раскрыть свои таланты;

- создавать инновационные образовательные программы;

— вводить в образовательный процесс новые технологии;

- разрабатывать новые технологии.

Для воплощения инновационных идей студент должен иметь определенные качества и умения:

1) стремиться к профессиональному самосовершенствованию;

2) обладать исследовательскими и организаторскими способностями;

3) проявлять инициативу;

4) быть целеустремленным и креативным;

5) уметь добиваться поставленной цели;

6) иметь лидерские качества.

Все эти перечисленные качества и умения определяют инновационный потенциал личности [5, с. 252].

Формирование инновационного потенциала внеаудиторной деятельности будет более успешным, если осуществить переход к использованию современных методов и технологий обучения, которые способствуют развитию инновационной деятельности. Результатом сформированных компетенций выступает инновационная активность, которая определяет степень готовности студентов к инновационной деятельности. 
Готовность к инновационной деятельности предполагает сформированность системы мотивов, знаний, умений, навыков, профессионально и личностно значимых качеств, компетенций студентов, без которых невозможно разработать и внедрить новинки в профессиональную сферу [5, с. 17].

Инновационная активность зависит от уровня интеллектуального развития и степени проявления творческих способностей. Одним из средств формирования этой активности является проектная деятельность студентов. Благодаря проектной деятельности приобретается личный опыт, появляется возможность использовать свои разработки на практике.

Нововведения во внеаудиторной деятельности позволяют молодому специалисту разрабатывать, осваивать и использовать педагогические новинки в процессе обучения и воспитания, помогают в организации инновационной образовательной среды учебного заведения.

Инновационная педагогическая деятельность в системе высшего образования - это деятельность, позволяющая находить, изучать, распространять, разрабатывать и внедрять педагогические и организационные инновации, осуществлять трансферу результатов фундаментальных и прикладных НИР в учебный процесс и создавать инновационную образовательную среду, которая направлена на повышение инновационной активности студентов [1, с. 15].

Таким образом, инновации во внеаудиторной деятельности позволяют:

- изменить содержание программ внеаудиторной деятельности;

- создавать и использовать новые технологии;

- находить средства, приемы и методы, помогающие осваивать новые программы;

- создавать условия для самоопределения личности в процессе внеаудиторной деятельности;

- изменить образ деятельности и стиль мышления преподавателей и учащихся;

- изменить отношения между преподавателями и студентами;

— создавать и развивать новые творческие коллективы, школы, вузы.

$* * *$

1. Владимиров А.И. Об инновационной деятельности вуза. - М.: ООО «Издательский дом Недра», 2016. -72 с.

2. Данилов Д.Л. Инновационный потенциал преподавателей российской высшей школы / Д.Л. Данилов; под ред. Г.Б. Кораблевой. - М., 2015. - 72 с.

3. Иванникова Л.В. Внеаудиторная самостоятельная работа как средство формирования профессиональной компетентности студентов-педагогов высших учебных заведений // Проблема процесса саморазвития и самоорганизации в психологии и педагогике: Сборник статей по итогам Международной научно-практической конференции (Самара, 23 ноября 2018 г.). - Стерлитамак: АМИ, 2018. - 237 с. - C.70 - 73.

4. Казанцев А.К., Фирсова С.А. Инновационные ресурсы высшей школы России // Инновации, 2016, № 7. $-222 \mathrm{c}$.

5. Куликова Л.Г., Лопаткин В.М. Развитие инновационных компетенций у студентов и аспирантов в системе учебно-научно-педагогического комплекса // Мир науки, культуры, образования, 2014, № 6(43). $-432 \mathrm{c}$.

6. Радчук А.П., Бунько С.А. Инновации в вузе: проблемы и перспективы // Вестн. Брест. гос. техн. ун-та, 2016, № 3. -204 c. 